\title{
Spill-Over Effect and Functional Illegality- Towards a Sociology of Gene Doping
}

\author{
Swen Körner \\ Institute of Pedagogy and Philosophy, German Sport University Cologne, Cologne, Germany \\ Email: koerner@dshs-koeln.de
}

How to cite this paper: Körner, S. (2017). Spill-Over Effect and Functional Illegality-Towards a Sociology of Gene Doping. Advances in Physical Education, 7, 60-69. https://doi.org/10.4236/ape.2017.71006

Received: February 6, 2017

Accepted: February 24, 2017

Published: February 27, 2017

Copyright $\odot 2017$ by author and Scientific Research Publishing Inc. This work is licensed under the Creative Commons Attribution International License (CC BY 4.0).

http://creativecommons.org/licenses/by/4.0/

\begin{abstract}
Numerous examples illustrate that modern societies tend to fail at controlling the fallout from medico-scientific progress. Technologies developed for medicine and therapeutics do not infrequently spill over into other social ambits to be repurposed. Within the area of emerging technologies, and necessarily linked to gene-therapeutical research, so called gene doping is discussed as promising form of illegitimate performance enhancement in elite sports at the moment. The following paper focuses on the relationship between elite sports and gene doping from a sociological point of view. For what social reason is sport likely to become an experimental field for the use of gene doping? In a first step, prevailing fantasies about gene doping as opposed to the current state of biomedical research are outlined. In a second step, 1) relevant social structures of modern elite sports are presented exemplarily, in order to 2) shed light on doping as a functional adaptation of internal expectations of the system. Considering this background, it becomes clear that the potential use of gene doping is highly expectable for elite sports. The contribution ends up with the conclusion that the promise of gene doping is functional and challenging for a large number of players inside and outside the world of sports.
\end{abstract}

\section{Keywords}

Gene Doping, Elite Sports, Spill-Over Effect, Records, Functionality of Doping

\section{Society, Technology \& Elite Sports}

In modern society, scientific and technological progress leads to a type of decision making which Calabresi and Bobbit (1978) described as Tragic Choices. The tragedy is situated in the fact that decision for and against technology can be treated as a risk. Instructive here is the example of the so-called CRISPR-technique in the context of genome editing. Using CRISPCas9, it seems that editing human genetic material is possible and with it alterations of the germline with 
yet unknown precision. In terms of biomedicine and health economy, the social benefits of CRISPCas9 are expected to be large; not-applying this technology is therefore a critical matter. However, using it is also associated with risks. For this reason, renowned pioneers in the field of biomedicine, among them the Nobelist Paul Berg, have called for a moratorium (Lanphier, Urnov, Haecker, Werner, \& Smolenski, 2015: p. 411; Regalado, 2015). While for some experts, CRISPCas9 raises unresolved society-wide ethical problems, for others it is simply a question of controllable technology ${ }^{1}$. Last not least, the issue of spillover effects is touched. Detailed plans for building the CRISPCas9 system can easily be downloaded by anyone from the Internet, making control of its application scarcely feasible; regardless of the question whether the technique works or which side-effects could occur. Numerous examples illustrate that modern societies tend to fail at controlling the fallout from medico-scientific progress (Luhmann, 1994: p. 61). For instance, technologies developed for medicine and therapeutics do not infrequently spill over into other social ambits to be repurposed. Amphetamines can make ADHD children settle down and keep soldiers awake, but they can also activate performance-limiting resources, for example in the modern athlete's body, where anabolic steroids and erythropoietin (EPO) have found their place as well. Neither of which were developed for athletic but instead for medical-therapeutic purposes. With regards to technological progress, trans-individual and trans-intentional dynamics take control on a regular basis.

Elite sports is a modern social system on a global scale. Based on the fictitious premise of equality, it focuses on the comparison of human achievement and thus the distinction between winner and loser. As such, the elite sports system has made up its decision already. In order to functionalize human perception, emotion, cognition and motor-action to its needs, elite sports search for new technologies. Technology allows for precise turning on and off of enhancement capacities (Körner, 2014: p. 165). Within the area of emerging technologies, and linked to gene-therapeutical research, so called gene doping is discussed as "ominous new opportunity on cheating technology" (Friedman, 2010: p. 20) in elite sports. The following paper focuses on the relationship between elite sports and gene doping from a sociological point of view. For what social reason is sport likely to become an experimental field for the use of gene doping?

In answering this question, following steps will be undertaken: in a first step, prevailing fantasies about gene doping, as opposed to the current state of biomedical research, are outlined (2). In a second step, (a) relevant social structures and conditions of modern elite sports are presented exemplarily, in order to (b) shed light on doping as a functional adaptation of internal expectations of the system (3). Considering this background, it becomes clear that the potential use of gene doping is highly expectable for elite sports (4). The contribution ends up with the conclusion that the promise of gene doping is functional and challenging for a large number of players inside and outside the world of sports (5).

${ }^{1}$ Notably, nothing resembling a debate on this has taken place in Germany. 


\section{Gene Doping-Conceptual Blurs and Molecular Target Points}

Potential gene doping is necessarily linked to the achievements in gene therapeutical research. Whilst its actual and future potential as well as its risks are evaluated very controversially, the cloned athlete has already entered the public-media stage. Visions of gene optimized athletes have become a real utopia of elite sport's future. Within the domain of organized sports (World Anti-Doping Agency) and sports science, the term "gene doping" is used in a narrow and a wide sense of meaning (Körner et al., 2016: p. 19). Narrowly defined, gene doping is the transfer of genetic material (DNA or RNA) into a cell, an organ, or an organism. The delivery of the DNA or RNA takes place through the misuse of gene cell and cell therapeutic processes. In a broader sense, gene doping is also understood as a deliberate modulation of gene activity by other methods (e.g., the taking of pharmacologic substances).

The World Anti-Doping Agency (WADA) until 2011 exclusively used the expanded understanding of the term, defining gene doping as the "non-therapeutic use of cells, genes, genetic elements, or the modulation of gene expression having the capacity to improve athletic performance" (WADA, 2011). In the revised version of WADA's prohibited list in force since 01.01.2017, "the following methods with the potential to enhance sport performance are prohibited: 1) The transfer of polymers of nucleic acids or nucleic acid analogs; 2) The use of normal or genetically modified cells." (WADA, 2017). The modulation of gene expression by pharmacological means is deleted from the revised version. This development can be understood as a reaction to the definition's oft-criticized terminological fuzziness. For instance, pharmaceutical substances like anabolic steroids have also been known for a long time to enhance athletic performance by modulating gene expression. In view of these conceptual blurs ${ }^{2}$ and contrary to populist "Freakshow" scenarios and fantasies about the cloned athlete, according to experts three molecular target points of gene doping (broader and wider sense) can currently be identified (Gerlinger, Petermann, \& Sauter, 2008: pp. 40-58; Friedman, 2010: p. 20; Beiter \& Velders, 2012: p. 126; Körner et al., 2016: p. 55).

1) Energy Supply. For instance, specific control and improvement are providedhere by methods for the overexpression of fat- and glucose-transport-proteins. Originally intended for the treatment of obesity and diabetes, the therapeutic application of FATP1, CD36 or GLUT serves as an attractive technology for sports performances.

2) Oxygen supply: Another likely application field of gene technological enhancement lies in the range of oxygen supply. Since the isolation of the human EPO gene in 1983, the attention is focused in particular on strategies to increase

\footnotetext{
${ }^{2}$ The problem of a selective definition, however, persists in the current version of the WADA prohibited list. For example, blood doping, strictly speaking, would fall under the gene doping definition since it also involves the use of cells. A solution to the problems of defining "gene doping" is not in sight. Any future discussion to this effect will also have to take into account epigenetic modifications of gene expression, an area where research is still in its infancy.
} 
the concentration of erythrocytes, which indirectly lead to an improvement in the oxygen uptake and transport capacity. Numerous doping cases of recent years demonstrate the use of pharmacologically produced EPO, particularly in intensive endurance sports. The next stage involves gene therapy methods for intramuscular administration of the EPOgene, which has already appeared in the context of an investigation of a prominent former athletics coach (under the brand name Repoxygen ${ }^{\text {tw }}$, Oxford BioMedica).

3) Skeletal muscle system: Besides the use of genetically engineered growth hormones such as HGH (human growth hormone) and IGF-1 (insulin like growth factors) primarily strategies for build-up processes deserve special attention, e.g. through the overexpression of the receptor protein PPAR-delta or through the blockage of the extracellular messenger myostatin by inhibiting RNA. The conversion of type II muscle fibers (fast fibers) into type I fibers (slow fibers) by modulation of PPAR delta receptors as well as the inhibition of the myostatin gene through inhibitory RNA lead to a hypertrophy of the muscle and an increase of the number of fibers (hyperplasia). Both processes have already been demonstrated in animal experiments ("marathon mice", "knock-out mice") and were partially converted into clinical trials.

Like conventional doping, gene doping is a risky technology which has to count in the boundaries of simplification (Friedman, 2010: p. 20). Even if a few promising results in animal and clinical studies have to be stated, the use of methods and substances for the modification of gene activity is linked to risks and side effects. Immune reactions or uncontrollable cell growth hint to potentially massive health problems which can lead to death (Friedman, 2010: p. 21; Beiter \& Velders, 2012: p. 128).

Despite the biomedical fact of its temporary impracticality, gene doping interestingly is surrounded by a mystique of causality, evoking sociological attention. Even though gene doping currently cannot do what it professes to do, it seems that modern elite sports could not care less about those scientific arguments. Elite sport is addicted to human enhancement, even to fictions about it. The prospect of a genetically based push of a button technology is enough for it. To the extent that gene doping has the reputation that it can plumb the last riddles of human performance enhancement in the microenvironment of the genes, the eigenfrequencies of the sport system begin to oscillate. A few years ago, when a gene therapeutic procedure for intramuscular application of the EPO genecame out in the form of Repoxygen ${ }^{\text {tw }}$, a veteran German track and field coach immediately expressed interest in buying and using it (Beiter \& Velders, 2012: p. 127). The mentality and the practice of doping is an empirically constitutive fascination of modern elite sports. Why is that?

\section{Doping-Functional Illegality of Modern Elite Sports}

Within public, sport and science, it is quite usual to deal doping above all as a question of individual behavior. The doped athlete then becomes the lightning rod for (dis) esteem. Athletes who have been accused to doping are widely re- 
ferred to in popular parlance as "doping sinners"-the metaphor implies the depth of the guilt assigned. In this case, doping is not an accidental slip-up but a question of substantive traits that come to define a sports personality like a shadow. Lance Armstrong, for instance, then flatly becomes The Inhuman (Hecker, 2013), something that was obvious all along somehow. Unlike barely discernible social structures, athletes made of flesh, mind, and blood can be very convincingly stereotyped as the cause of the doping problem. They can be addressed, gone after, asked for a urine sample, condemned or absolved of blame. In a typical modern epistemic understanding, athletes are the deciders who weighed alternative rational actions against cost-benefit consequences and then decided to reach for doping. In doing so, it is not just substance-based addictive behavior that is ruled out. The left out perspective above all is the role of powerful social structures that can also be understood more or less directly as expectation structures, which athletes must come to terms with day after day. Meanwhile, a brief exemplary look at those socio-structural constraints, which predispose to individual behavior and co-produce it, is worthwhile. With that said emerges an alternative explanation for doping as well as for said fascination with the fictionalized fact of gene doping.

\subsection{Social Structures}

The elite sports system is a part of the modern society which holds up performance, its comparison and enhancement within a rigid logic of competition. One indication of this is the relevance and prominence of records, rewarding absolute physical performances, which in turn deliver a bearing structure of expectation. While its technical side (recording) conflates the screening horizons of alter and ego even as they drift through time and space, the informational side (reference to peak performance) of records motivates follow-on action (surpassing). All the shooting, hitting, throwing, running, etc. can orient itself directly or indirectly to beating existing records. In some disciplines like cycling, 100-meters-race or pole vault, we can observe rates of performance enhancement between 24 and 221 percent since the first modern Olympic Games of Athens in 1896 (Nature Materials, 2012: p. 651). Records illustrate the modern elite sport's paradigm of "pushing the boundaries", and they show of how boundaries of today regularly turn into the mediocrity of tomorrow. Records bridge the distance between the present and the past, the living and the dead, and enable sport to observe its own operations as special operations. On a second order level of observation, records respond to records. To sum it up, for the modern sports system, records are attractors that cannot be circumvented. This orientation gives rise to the expectation that athletes will tailor their actions accordingly. Added to that, records are exchangeable into other, socially high-profile recognition currencies: they lead to social attention and fame.

Structural incentives in the same direction are set by the financing and selection criteria operating on the national stage. For instance, in Germany the so-called chance to be in the final or the instrumentality of goal setting contracts 
between the Interior Ministry, the German Olympic Committee, and elite sports organizations deliver as expectation structures that put a premium on peak performance and above all on success-not ethics or simple performance comparison. This is where the idea of fairness comes up against the citius, altius, fortius trinity. References to the spirit of fairness of sports run like a common thread through the official program structure of its national and international organizations. With that said, however, it is not without a certain irony that there already wafts a split "spirit of sport" on the level of objectives, settled in between expectations of doping-abetted top performances and a fairness ethic that prohibits doping. Modern homo sportivus thus takes the field as the tension-filled social hybrid made up of the "reasonable man", the "gentleman", and the Mortal Engine (Hoberman, 1992). On one side, the athlete is strictly obligated to behave in keeping with the concept of competitive play. There is no option but fair play. On the other side, there are the results-oriented expectations of succeeding and moving up. However that turns out: as a modern subject, the athlete is responsible for his or her actions. With some success, organized sport projects an image of the ethical operator, and it is one that it will not give up. Simultaneously, it ties all relevant selection and sponsoring criteria to top performances or wins. This means that the decoupling of Talk, Decisions, and Actions (Brunsson, 1989) is part of the structure of organized sport. It exposes it to accusations of organized hypocrisy.

In order to functionalize athletes' bodies and minds according to its structural needs, elite sports look for technologies (Fuss, Subic, \& Mehta, 2008). The selfdirected proximity of elite sports to technology is based on a simple promise: namely, to isolate defined areas of complex system-environment-relations within which in turn defined elements can be systematically linked according to the scheme of cause-and-effect ${ }^{3}$. Technologies promise control, regulation and prognosis. They allow the expectation that differences and enhancement can be shown precisely even at a point where the potential of human physiology and biomechanics are exhausted. Following this logic, the application of-for exampleEPO leads to an increase in red blood cells, which in turn leads to a heightened capacity for oxygen intake, which ultimately leads to an increased probability of athletic success. However, some technologies and methods are prohibited and sanctioned as doping. In the following it is argued that all of them are functional to elite sports: doping, its ban as well as its control.

\subsection{Functional Illegality}

1) Functionality of doping: With the view of elite sports structural conditions, doping, prohibition of doping, and controlling can be explained in a different

\footnotetext{
${ }^{3}$ Technology, defined as "functional simplification in the medium of causality" (Luhmann, 2003: p. 97), thus as an isolated area of complex system-environment relationships, within which defined elements can be linked according to a cause-effect schema. Doping technologies postulate a realism effect, a targeted turning on and off of performance-related parameters: using x (e.g., EPO, testosterone) causes $\mathrm{y}^{1}$ (elevated red blood cell count, increased muscle mass), which results in $\mathrm{y}^{2}$ (higher oxygen uptake, explosive power) causes z (higher probability of athletic success).
} 
manner, namely as a problem solution with an intrinsic systemic value character. From a functional perspective, doping serves to compensate for effects that competitive sport itself produces. Competitive sport expects top performance and simultaneously the highest moral. Doping ensures, or at least promises that performances do not regress but trend upward and boost chances of athletic success. As a technology it kicks in where legitimate means for influencing supposed or actual performance-limiting physical and mental processes run into natural limits.

2) Functionality of the doping ban: While doping innovatively services the side of technological performance expectations, the ban of doping embarked in the 1960s squarely puts it between the guide rails of an ethic that has more to it than merely abiding by the rules of the game. If a sprinter comes out of the blocks early or a boxer bites, these are rule infractions that are handled adaptively during the competition and that occasionally give it a different but entirely envisaged direction. They yield a new competitive scenario, a restart (with disqualification), deduction of points-tension and excitement, yes, but still not the strong ethical expectation of elite sports. Its strong morality comes from sport imposing a ban on specific technologies, from monitoring compliance, from sanctioning the revealed disregard and sweeping it into the depths of character-based motivations. Athletes that self-administer EPO are guilty of dopingathletes that train or sleep in hypoxic chambers are not guilty of doping-even though the effects are comparable. The doping ban concerns a historically and factually contingent but nonetheless ultimate norm. The norm stabilizes itself through compliant and deviant behavior. The expectation of "clean sport" is not in the least the result of flouting it. Just as doping conversely is observable only because the expectation of a sport without doping had been able to establish itself as a sanctionable norm. Not in spite of the existence of doping but because of it can there be "clean sport", its strong ethical expectation.

3) Functionality of doping control: The world wide organized controlling of athletes, too, is functional. In case of a positive doping test, the test result stabilizes the trust in the efficacy of the controls and the problem's containability. It is organized sport signaling that the doping problem must be taken seriously. At the same time, convicted bodily fluids turn the scrutiny on the individual doping sinners, who are ejected regularly with pronounced indignation while the action continues without interruption. To that extent, doping is "functional illegality" for organized sport (Luhmann, 1976: p. 304). By contrast, every negative test also stabilizes the belief in a clean, i.e. fair, natural, and healthful competitive sport that is still human. Competitive sport moves on both sides of the distinction, it performs its societal reproduction and adaptability as a union of the difference between compliance and deviance. Fairness (not to dope) has its function and so does doping.

\section{The Power of Fictionalized Facts}

There are many fields of human endeavor in which the individual's genetic 
make-up plays a decisive role in ultimate results. The modern elite sports system is definitely one of those. As stated before, doping in elite sports is highly functional and can be outlined as "functional illegality" (Luhmann, 1976: p. 304). Yet, gene doping is all promise at the moment. For one thing, because targeted experiments or use on the athlete's body to actuate and control molecular-genetic regulatory mechanisms are nothing less than farfetched. There are no documented cases of gene doping within the domain of doping control. However, with regard to gene doping a not-yet has to be distinguished from a not-ever (Reyer, 2003: p. 14). While in the first instance (the not-yet) it is a question of technological development and ultimately of time, with not-ever we are dealing with a normative argument: why in the final analysis, we would not, could not, and possibly should not want to, despite it being technically feasible. Rapid progress in biomedicine over the past seven decades tells us that questions of societal acceptance are decided by yardsticks that historically evolve in parallel. A conspicuous example in the area of human reproduction of how a not-ever can turn into a principled why-not is the progressive lifting of national prohibitions on legalized abortion procedures (1976) to approving limited preimplantation genetic screening $(2011)^{4}$. Value standards have evolved; the current trend is toward reproductive self-determination (Reyer, 2003: p. 182).

The durability of long-established norms in the face of technological leaps should not be overestimated. Modern societies often fail at controlling the fallout from medico-scientific progress (Luhmann, 1994: p. 58). Spill-over effects of technology being re-purposed in other domains of social life can be observed on a regular basis. If it goes well, Teflon pans emerge. It can also run differently. It is just as much an expression of the typically modern disruption of interdependence that it is possible to rig a bomb at home at your desk with the help of plans posted on the Internet, or to synthesize doping substances and distribute them for high profits around the world in the shadows of organized crime. That we should be prepared for deviations from normative expectations finally is also evident in what is happening in the context of the elite sport system.

Gene doping is all promise in a second sense. Even though, and as pointed out before, the cloned athlete-as the real utopia of tomorrow's elite sport-currently springs from a fantasy: for sports, the fictionalized fact suffices. And, apart from that, the about-face by the World Anti-Doping Agency in 2003, when it added gene doping in premature haste to the list of prohibited substances and methods, also speaks volumes in this regard. Never mind pointing out to sport how speculative the whole thing is. The argument is academic. Ordered knowledge is one thing, the logic of practice within the world of sports and the power of fictionalized facts is something completely different. Once available, gene

${ }^{4}$ So, for an artificial starting point, from the so-called Genetiker Manifest [Geneticists Manifesto] (Muller, 1939) through Genetic Counseling projects in the 1940s all the way to the vision of Biological Future of Man (Lederberg, 1963) by engineering the human germline. Interestingly, these developments were also always concerns of avowed eugenicists (Lederberg received the 1958 Nobel Prize in Medicine). In the debates taking place since the late 1990s over embryonic stem cell research and pre-implantation diagnostics, eugenic references run more or less as a subtext alongside. 
doping in elite sports as a spill-over effect from gene therapeutic research is more than likely.

\section{Conclusion and Further Research}

From a sociological point of view, individual behavior and collective orientation within the field of sports are related to its social structures. Considering the powerful social constraints of modern elite sports, it has become clear that the spill-over of gene doping is more than likely-regardless of currently missing evidences of use. Gene doping is functional illegality in a sense of fulfilling internal expectations of athletic enhancement by innovative means.

Just like the doping debate, the public and scientific debate on gene doping is one of many voices. And like doping, gene doping-no doubt triggered by the magic word "gene" immediately conjuring up a sort of second-order anthropology-is also dope on which many parts of modern society are hooked. With regard to questions of functionality, a multitude of social dynamics triggered by gene doping can be assumed. For instance, it is clear that the biochemists, with an eye on gene doping, will definitely not stop analyzing bodily fluids and honing new detection methods. Education and doping prevention are also not about to cease their best-intentioned work of fostering informed decision making of underage athletes. Doping and gene doping are also grist for the mills of mass media as well as for legal and ethical functionings: it can be reported on with gripping images and headlines, judgement can be soberly pronounced on it, or it feeds talk about the wit and worth of sports. The sports public, too, is not far behind. It consumes sport but equally the indignation over a doped sport. When it comes to doping and gene doping, modern society is fascinated. Once started, it reacts to turbulences it has a hand in generating.

For a sociology of gene doping, all of the mentioned social dynamics require detailed analysis in the future. Further research has to face gene doping's impact inside and outside the world of sports. Along with the possibility of gene doping, key questions on moral standards in elite sports are touched. What kind of sports do we really want? There is some evidence for the fact that the modern society in sport is leading moral debates vicariously for itself: about the social role of fairness, their relationship to the optimization of physical performance as well as about desired and non-desired impacts of technology. Last not least gene doping is about the big picture: the question of human being, his nature and dignity, which has always been caused a dynamic of changing answers.

\section{References}

Beiter, T., \& Velders, M. (2012). Pimp my genes-Gendoping zwischen Fakt und Fiktionen. Deutsche Zeitschrift für Sportmedizin, 63, 121-131. https://doi.org/10.5960/dzsm.2012.019

Brunsson, N. (1989). The Organization of Hypocrisy. Talk, Decisions, and Actions in Organizations. Chichester: John Wiley \& Sons Inc.

Calabresi, G., \& Bobbitt, N. (1978). Tragic Choices. New York, NY: W. W. Norton \& Company. 
Friedman, T. (2010). How Close Are We to Gene Doping? The Hastings Center Report, 40, 20-22. https://doi.org/10.1353/hcr.0.0246

Fuss, F. K., Subic, A., \& Mehta, R. (2008). The Impact of Technology on Sport-New Frontiers. Sports Technology, 1, 1-2. https://doi.org/10.1002/jst.5

Gerlinger, K., Petermann, T., \& Sauter, A. (2008). Gendoping. Wissenschaftliche Grundlagen-Einfallstore-Kontrolle (Studien des Büros für Technikfolgen-Abschätzung beim Deutschen Bundestag, 28). Berlin: Editon Sigma. https://doi.org/10.5771/9783845269924

Hecker, A. (2013). The Inhuman [Der Unmenschliche]. Frankfurter Allgemeine Zeitung. http://www.faz.net/aktuell/feuilleton/lance-armstrong-der-unmenschliche-12028487.html

Hoberman, J. (1992). Mortal Engines. The Science of Performance and the Dehumanization of Sport. Human Engineering and the Transformation of Sport. New York, NY: The Free Press.

Körner, S. (2014). Technology Assessment of Elite Sport. A Systems Theoretical Approach to Doping of the Next Society. Athens Journal of Sports, 1, 163-172.

Körner, S., Schardien, S., Steven-Vitense, B., Albach, S., Dorn, E., Arenz, T., \& Scharf, M. (2016). Gene Doping - The Future of Doping? Teaching Unit-Gene Doping in Competitive Sports. Frankfurt am Main: Peter Lang. https://doi.org/10.3726/978-3-653-06346-2

Lanphier, E., Urnov, F., Haecker, S. E., Werner, M., \& Smolenski, J. (2015). Don't Edit the Human Germ Line. Nature, 519, 410-411. https://doi.org/10.1038/519410a

Lederberg, J. (1963). Biological Future of Man. In G. Wolstenholme (Ed.), Man and His Future (pp. 263-273). London: Churchill. https://doi.org/10.1002/9780470715291.ch17

Luhmann, N. (1976). Funktionen und Folgen formaler Organisation (4th ed.). Berlin: Duncker \& Humblot.

Luhmann, N. (1994). Gesellschaftsstrukturelle Bedingungen und Folgeprobleme des naturwissenschaftlich-technischen Fortschritts. In N. Luhmann (Ed.), Soziologische Aufklärung 4. Beiträge zur funktionalen Differenzierung der Gesellschaft (pp. 49-66). Leverkusen: Westdeutscher Verlag.

Luhmann, N. (2003). Soziologie des Risikos. Berlin: De Gruyter.

Muller, H. J. (1939). Social Biology and Population Improvement. Nature, 144, 521-522. https://doi.org/10.1038/144521a0

Nature Materials (2012). More than Training. Editorial. Nature Materials, 11, 651. https://doi.org/10.1038/nmat3399

Regalado, A. (2015). Engineering the Perfect Baby. http://www.technologyreview.com/featuredstory/535661/engineering-the-perfect-baby/

Reyer, J. (2003). Eugenik und Pädagogik. Erziehungswissenschaft in einer eugenisierten Gesellschaft. Weinheim: Juventa.

World Anti-Doping Agency (WADA) (2011). The 2011 Prohibited List. International Standard. https://www.wada-ama.org/sites/default/files/resources/files/WADA_Prohibited_List_ 2011_EN.pdf

World Anti-Doping Agency (WADA) (2017). The 2017 Prohibited List. International Standard. https://www.wada-ama.org/en/prohibited-list 
Submit or recommend next manuscript to SCIRP and we will provide best service for you:

Accepting pre-submission inquiries through Email, Facebook, LinkedIn, Twitter, etc. A wide selection of journals (inclusive of 9 subjects, more than 200 journals)

Providing 24-hour high-quality service

User-friendly online submission system

Fair and swift peer-review system

Efficient typesetting and proofreading procedure

Display of the result of downloads and visits, as well as the number of cited articles Maximum dissemination of your research work

Submit your manuscript at: http://papersubmission.scirp.org/

Or contact ape@scirp.org 